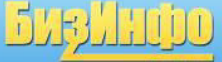

Часопис из области економије менаџмента и информатике

Година 2018, волумен 9, број 2, стр. 11-26

\section{D) $\left.]-/ \int\right]=0$}

Journal of Economics, Management and Informatics

Year 2018, Volume 9, Number 2, pp. 11-26

Оригиналан научни рад/ Original scientific paper

УДК/UDC: $338.483 .12: 725(497.11)$

doi: 10.5937/bizinfo1802011J

\title{
TOURIST OBJECTS OF ALEKSANDAR ĐOKIĆ, AN ARCHITECT: NATIONAL AND INTERNATIONAL STYLE CHARACTERISTICS
}

\section{ТУРИСТИЧКИ ОБЈЕКТИ АРХИТЕКТЕ АЛЕКСАНДРА ЂОКИЋА: НАЦИОНАЛНЕ И ИНТЕРНАЦИОНАЛНЕ СТИЛСКЕ КАРАКТЕРИСТИКЕ}

\author{
Aleksandra Jevtovic ${ }^{1}$ \\ Business School of Applied Studies in Blace, Serbia
}

\begin{abstract}
Facilities intended for tourist accommodation and dining are an integral part of the tourism system. In addition to the role of providing certain services, architectural objects can also have the status of cultural attractions of a particular destination. The architectural objects of the famous artists are part of the cultural heritage, and according to their stylistic characteristics, they can be viewed as part of the worlds or national cultural heritage. Architect Aleksandar Đokić was famous Serbian architect and one of the most productive creators of his time. In his rich opus, numerous facilities are intended for use within the tourism system framework. Regarding author's unique expression, which was created under the impact of various influences, we distinguish holders of international and national stylistic characteristics within his works. The aim of this study is to illustrate interdependence of the architecture of the tourist facilities and the ruling ideology, as well as their consequences on tourism, through the case study of four selected Đokić's projects.
\end{abstract}

Key words: tourism, architecture, ideology, heritage, Aleksandar Đokić.

Резиме: Објекти намењени за смештај и исхрану туриста чине интегрални елемент туристичког система. Поред улоге у пружању

1 aleksandra.jevtovic@vpskp.edu.rs 
одређених услуга, архитектонски објекти могу имати и статус културне атракиије одређене дестинације. Архитектонски објекти знаменитих стваралаца део су културне баштине, а према својим стилским карактеристикама могу се посматрати као део светске или националне културне баштине. Архитекта Александар Ђокић био је знаменити српски архитекта и један од најпродуктивнијих стваралача свог времена. У юеговом богатом опусу бројни објекти су намењени употреби у оквирима туристичког система. Како је реч о аутору оригиналне изражајности, који је стварао под дејством најразличитијих утицаја, међу његовим делима разликујемо носиоце интернационалних и националних стилских карактеристика. Циљ рада је да, кроз студију случаја четири одабрана Ђокићева пројекта, укаже на међуодносе архитектуре туристичких објеката и владајуће идеологије, као и на нихове последице по туризам.

Кључне речи: туризам, архитектура, идеологија, баштина, Александар Бокић.

\section{INTRODUCTION}

Architectural buildings are important elements of the tourism system which contribute to the attractiveness of the tourist destination. The destination's suprastructure, besides, can be the main cultural attraction and the main reason for visiting a specific area (cultural monuments and museums). It also has an inevitable role in providing a range of services to visitors during their stay at the destination (accommodation facilities, recreational facilities, catering and sales facilities, and other) (Popesku, 2011). One of the key features of modern trends in the tourism market is the competitiveness between tourist destinations (Popesku, 2011, p. 107). It is possible to analyze tourist facilities as one of the means for achieving competitiveness. The tourist facilities' architecture is undoubtedly one of the factors which contribute to the quality of the tourist product (Čomić, 2015), but it's also a mean of promoting the destination's identity. From the aspect of destination's national identity, we distinguish two types of objects: objects which fit into world trends, i.e. the international style architecture, and objects which promote affiliation to a certain area, i.e. the national style architecture.

It should be pointed out that both of these types of objects can contribute to the attractiveness of the destination. Frank Owen Gehry's objects are an example of the architecture that, according to its stylistic characteristics, is completely different from the environment in which it originates. Although these objects primarily testify to a powerful authorial expression and sculptural thinking of their creator, they lean towards the deconstructive and high-tech trends. Gehry's "Dancing House", co-authored with the CroatianCzech architect Vlado Milunić, was built in Prague (1992-1996) and is 
surrounded by rich architectural history: neo-baroque, neo-gothic and secession. Over time, it had become essential destination for tourists during a tour of Prague and one of the city's main symbols (Prague Experience; Prague.eu The Official Tourist Website for Prague).

As an example for the thesis where the architecture inspired by national history in particular contributes to the destination's attractiveness, the architecture of Antoni Gaudi (1852-1926) in Spain is prominent (Kolins, 1997; Cerbst, 2001). The buildings created by Gaudi eventually became a hallmark of Barcelona and one of the main reasons for visiting this city. Their author, inspired by the Catalan architecture, had created authentic works which represent this country's prominent cultural resource in the tourist offer for almost a century (Whitfield, 2018; Barcelona Tourist Guide). They're also constitutive element of the Spain's national identity and ensure the recognition of the destination at the global tourism market level.

In both examples, we recognize original authors whose architecture carries the hallmark of sculpturality and expressiveness. This common feature indicates that the authentic works of creative individuals are one of the most important resources in tourism, hence considered to be part of a broader concept of cultural heritage (Šastel, 1988). Among the tourism market environment changes, the most important are the changes on the demand side, which imply an increasing need for content in the cutural domain (Bakić, 2010, p. 295). A more detailed analysis of the tourist facilities' architecture contributes to future development strategies of tourist activity within particular destination and the wider region.

\section{ARCHITECT ALEKSANDAR ĐOKIĆ}

The prominent Serbian architect Aleksandar Đokić (1936-2002) was engaged in urban planning and architectural design during his career. He had built a large number of objects for different purposes, the largest number being on the Serbian territory, along with the several facilities on the Montenegrin coast (Маневић, 1995).

It's extensive construction work includes numerous tourist objects, among which we recognize both of these types. As a creator, Đokić expressed "an equal attachment to national artistic roots as well as to international flows in architecture" (Kadijević, 1996, p. 96). His authorial stylistic expression was built gradually, whereby during the first two decades he was predominantly accepting the influence of world architecture's current trends (Manević, 1982, p. 17). For the next two decades, in his mature stage of creation, he was creating in the spirit of national tendencies which he modernly interpreted (Кадијевић, 2007, p. 340, 342). In the domestic architectural scene's context, 
Đokić is part of the powerful expressive language creators' circle, characterized by romantic orientation (Маневић, 1990). Although he was creating under different influences during his lifetime, in his stylistic expression, the boldness in exploration of forms and expressionist tendency were continually expressed (Alfirević, 2016, p. 162).

The cultural environment and social circumstances in which he was creating went through complex ideological changes, which also reflected the architecture of that period (Ignjatović, 2012). Đokić graduated from the Faculty of Architecture in 1960, and spent the first creative decade in an atmosphere that was encouraging the concept of artistic activities' synthesis (Маневић, 1995, р. 15; Štraus, 1991, p. 38). Socialist Yugoslavia was encouraging authorial architecture, in order to strengthen its "Third Way" in this way. Also, a large number of war sufferings resulted in extensive production of memorial objects on the territory of former Yugoslavia (Manojlović-Pintar, 2014). During the seventies, the building production on the country territory was intense and successfully followed the world trends regarding the building technology (Милетић-Абрамовић, 2007, р. 23-35; Štraus, 1991, p. 93).

In the last decade of the socialist Yugoslavia's existence, in the eighties of the twentieth century, with the weakening of the Communist Party's influence, there has been an increase in the ethnic nationalism and the emergence of postmodern architecture (Ignjatović, 2010).

Through the case study of four selected Đokić's projects which were created during the seventies and eighties, the advantages and disadvantages of designing tourist facilities in the national and supranational spirit will be pointed out, as well as the influence of the ruling ideology on the design and future use of these facilities.

\section{ALEKSANDAR DJOKIĆ'S TOURIST FACILITIES CREATED DURING THE SEVENTIES}

During the first two decades of his working life, Đokić collaborated with sculptors. The result of these cooperations were numerous projects for memorial purposes: monuments, memorial features, memorial parks and similar. Among his most important projects in this area, the project of the Memorial Complex and the Reception Center at Kadinjača near Užice (19761979 ) is distinguished. The co-author of this project was sculptor Miodrag Živković (1928), whose works, especially during the socialist period, had a special significance (Путник, 2014, p. 122). 
The memorial complex at Kadinjača belongs to a series of related "hipermonumental compositions", which were built during the 1960s and 1970s, in order to consolidate the ideology of the newly formed socialist society (Путник, 2013). It was built on the highest point of the Kadinjača in honor to the fallen soldiers of the Workers' Battalion and was solemnly revealed by Josip Broz Tito on September 23, 1979. The revelation of this monument was the central republican celebration attended by over one hundred thousand visitors, as well as delegations of the republics, provinces and the JNA (Yugoslav National Army) (Косин и Пилчевић, 1979). Đokić and Živković were awarded by the "Slobodan Penezić Krcun" muniment for the realization of this work, which was the largest municipal recognition in Užice (Пилчевић, 1979). The Memorial Complex was declared an immovable cultural property of great importance in 1979 (Стефановић, 2010, p. 172).

Picture 1: The monumental parts of the complex at Kadinjača, M. Živković and A. Đokić, 1976-1979.

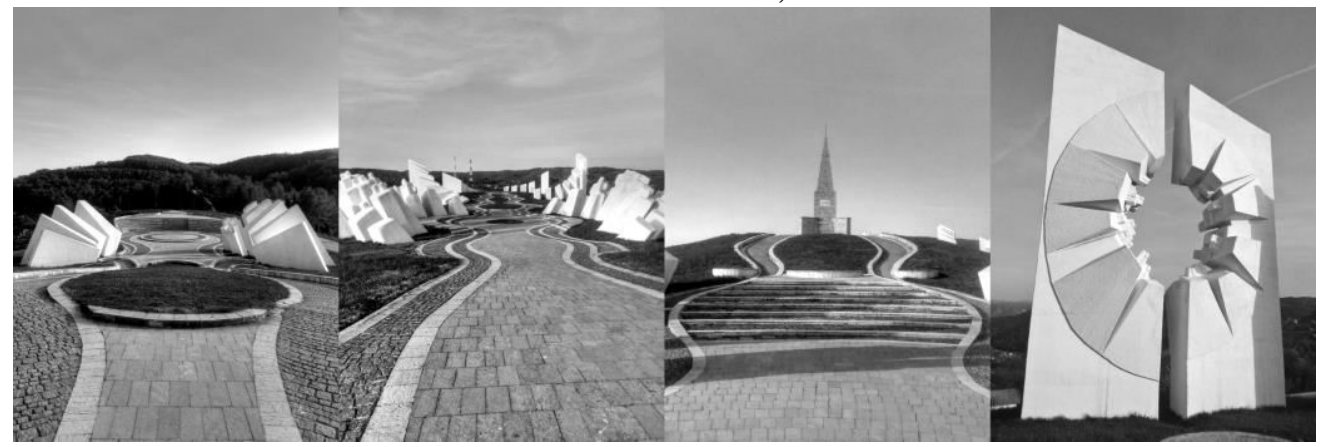

Source: photo of the autor of the paper, 2013.

The main part of the complex is an urban-sculptural solution to the battle's monument, a lyrical form at the basis, consisting of three parts: the Amphitheater of the Užice's Republic, the Alley of the Workers' Battalion and the Plateau of Freedom. As it was planned that the complex eventually become a tourist attraction, the Reception Center was built next to it, as an integral part of the monumental space (Đokić, 1980, p. 17). The facility provided tourists with a short stay on site, provided dining services, as well as information about historical events at Kadinjača.

Along the access road, the fountain is positioned, from which the stairway leads to the elevation where the monumental parts are located. The first in the series, Amphitheater of the Užice's Republic, consists of an open scene and sculptural masses of geometrical forms. This space is intended for manifestations, and the sculptor masses symbolizes the resistance of fighters. Furthermore, the composition leads to the memorial pyramid built in 1952, based on the Stevan Živanović's project (Стефановић, 2010, p. 163), which 
is included in the newly formed Đokić's and Zivković's spatial solution as an integral part thereof. The second part of the complex, the Alley of the Workers' Battalion, consists of monolithic blocks distributed on both sides of the pathway. From these blocks, rounded edges, stylized faces of the fighters grow, so that these sculptures represent a transitional form from figural to abstract mass formation. In symbolic sense, this part of the complex indicates the unity and strength of the members of the Workers' Battalion (Đokić, 1980, p. 12). The third monumental part and the main dominant in space, the Plateau of Freedom, consists of geometric masses, which gradually rise to the central motif, 14 meters high. The accented monolith contains a circular shaped penetration, and from the inside of this stone mass are sprouting stylized heads of fighters.

Picture 2: Reception center at Kadinjača, view from parking (left) and from Amphitheater of the Užice's Republic (right), A. Đokić, 1976-1979.

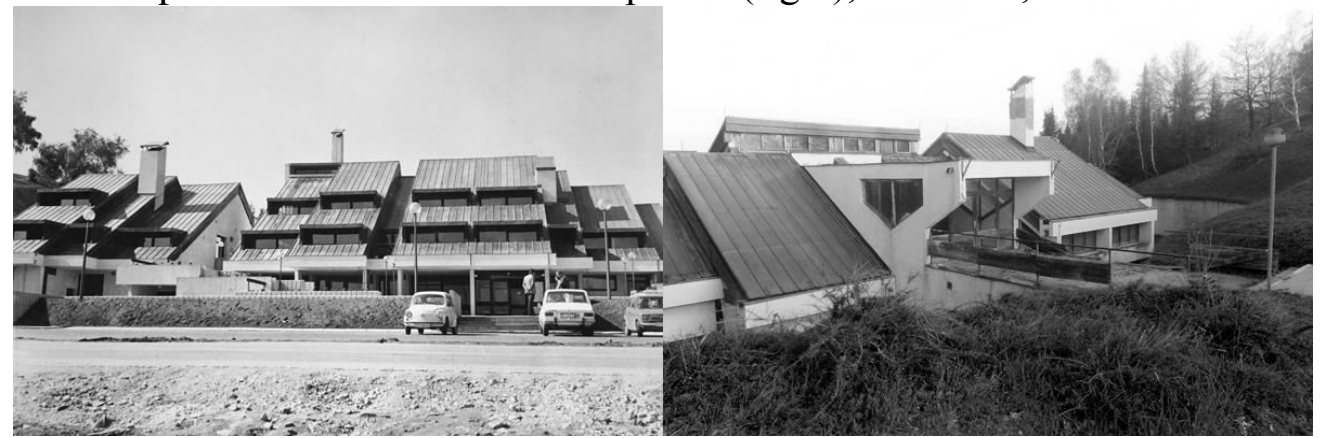

Sources: documentation from the bureau "Romantic architecture" (left); photo of the autor of the paper, 2013. (right).

The Reception Center building is located lateral to the monumental whole, and approach to it is provided from two directions: the access road and the memorial complex. It is partially buried in the terrain and shaped in the spirit of the traditional mountain house.

From the organizational point of view, the object is solved in three levels. On the ground floor, in front of the building, there is a spacious terrace along which the main entrance is located. The inner space is organized around the centrally positioned staircase and consists of information desk, seating space, lecture and exhibition activities hall and service rooms. Floor level consists of two parts between which access from the direction of the road is enabled. Most of the floor is occupied by a restaurant with a kitchen and a terrace, while offices and a janitor room are positioned at the side of the building. Above the restaurant, there is a gallery whose space is intended for exhibiton activities (Đokić, 1980, p. 18-19).

The construction of the Reception Center is made of glued laminated wood. Construction elements (wooden beams) were an integral part of the interior 
solution. In the exterior, these elements are protected by sheet metal in horizontal and sloping planes, while their vertical and lateral sides, protected by coatings, remain visible. Using this constructional manner, the unity of the exterior and interior of the building has been achieved (Kujundžić, 1980, p. 45-46).

In this building in 1985 a permanent museum exhibition "Workers' battalion and fight on Kadinjača" was set up, and since 1999 it has been constantly exposed as well the exhibition "Užice's region in the NATO aggression against FR Yugoslavia" (Стефановић, 2010, p. 169, 174). It is noted that during the socialist Yugoslavia the memorial complex on Kadinjača, which was at that time the organizer of numerous cultural events, had been visited by over two million and three hundred thousand domestic and foreign tourists (Стефановић, 2010, p. 175-176). During the 1990s, the number of tourists shrank to twenty thousand, and in the first decade of this century, the slight increase is recorded (Стефановић, 2010, p. 81). According to documentation from the National Museum in Užice, during 2011-2017 conservation and restoration project on monumental units, renovation projects of the reception center and renovation of the decorative lighting of the complex was completed.

In the same period, during the second half of the seventies of the previous century, Aleksandar Đokić was the author of the resort "13. May" (19761980) in Bečići in Montenegro. The co-authors on this project were architects Miodrag Radošević and Slobodan Zirojević (interior).

Picture 3: The former look of the resort "13. May" (above) and today's look of the hotel "The Queen of Montenegro" (below).

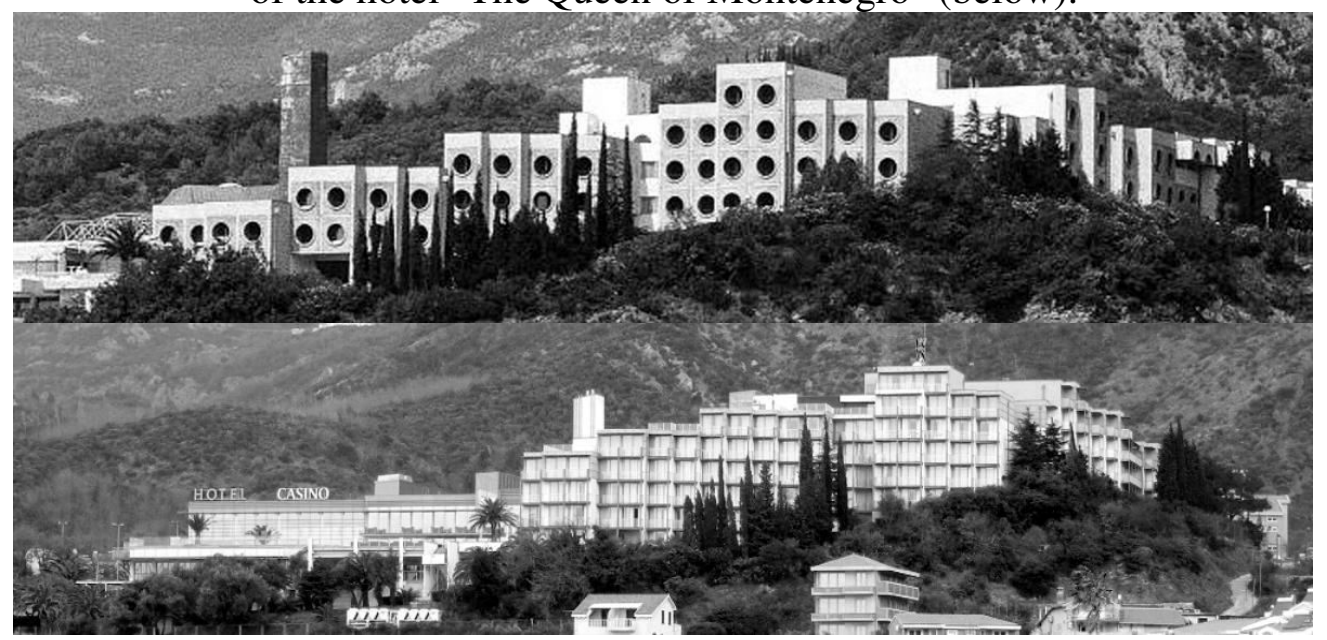

Sources: http://www.alfa-

tours.com/largeimages/003\%20Becici\%20Hotel\%20Panorama\%201.JPG (above); http://www.vijesti.me/ekonomija/hotel-the-queen-of-montenegro-ide-na-prodaju-zbogneplacanja-kredita-148983 (below).) 
The building is located near the coast, at a prominent altitudinal place. The south facade of the building is oriented towards the sea, while the main access to the resort is positioned on the north side. In the interior, the main role is played by the central hall with atrium and greenery, around which all the rooms are positioned. On the ground floor, in the northern part next to the entrance to the building, the reception and the administration premises are positioned. On the lateral, west side, a banquet hall and a breakfast area are located, which continues in a spacious terrace oriented to the coast. In the central part of the hall, a circular based bar is formed, while the accommodation units are positioned on the south side. On the typical floor of the building, all accommodation units are oriented towards the sea, while on the northern part the common room is situated, as well as a billiard room and a TV room.

The building was designed under the influence of the avant-gard trends of that time. The canopy at the entrance to the building was made of a spatial grid that penetrated into the interior of the building as an attractive interior element (Маневић, 1995, p. 82). This usage of the lattice structure originates from structuralism. Jagged silhouette of the building followed the soil configuration. The main facade, to which all accommodation units were oriented, consisted of mutually sheared vertical cubes. By repeating the circular perforations on its facade, the object got a Metabolist character. At the time of its construction, this building was following some of the worlds most current trends, and in support of this thesis is indicated by the fact that Nakagin capsules in Tokyo, an object that symbolizes the direction of Metabolism, were built in 1972. In an aestetic sence, the object's character is completely international. It belongs to Đokić's stage in which he experimented with geometric shapes and was creating under foreign influences. The building is still performing its original function and provides accommodation to tourists. Over time, it was changing owners and titles, and with its last adaptation, the original architectural expression was completely altered. Facade membranes with perforations were replaced by a glass wall curtain. Thereby is the former object of a strong identity redefined into a mere reflection of the surrounding nature, which is again in the spirit of the worlds architectural trends.

\section{ALEKSANDAR DJOKIĆ'S TOURIST FACILITIES CREATED DURING THE EIGHTIES}

In the eighties of the last century, postmodernism appeared on the domestic architectural scene, which was also the time of Djokić's creative maturity. During this period, one of his most prominent buildings - the House of Yugoslav-Norwegian Friendship (1981-1987) was built in Gornji Milanovac (Alfirević, 2016, p. 124). 
In Gornji Milanovac, in the seventies, the memorial park "Hill of Peace" was erected, in memory of the Yugoslav fighters, who were killed in Norwegian camps during the Second World War, and the friendship of these two nations, born during the war troubles (Đokić, 1984, p. 40). The house of the Yugoslav-Norwegian friendship was brought up with the idea of keeping a memento of the war events and in order to contribute to cooperation of the two nations in the future. It was planned that the facility serves as a colony for gathering of artists, for exchanging tourists with Scandinavian countries and to operate as a "specialized tourist organization" (Кубуровић, 1985). The ceremonial opening of the building took place in September 1987 and was attended by the Minister of Culture in the Government of the Kingdom of Norway, Norwegian Ambassador in Belgrade, members of the Presidency of the SFRY, three hundred guests from Norway and several thousand guests from Yugoslavia (Кубуровић, 1985).

\section{Picture 4: Model of House of Yugoslav-Norwegian friendship in Gornji} Milanovac, A. Đokić i V. Kujundžić, 1981-1987.

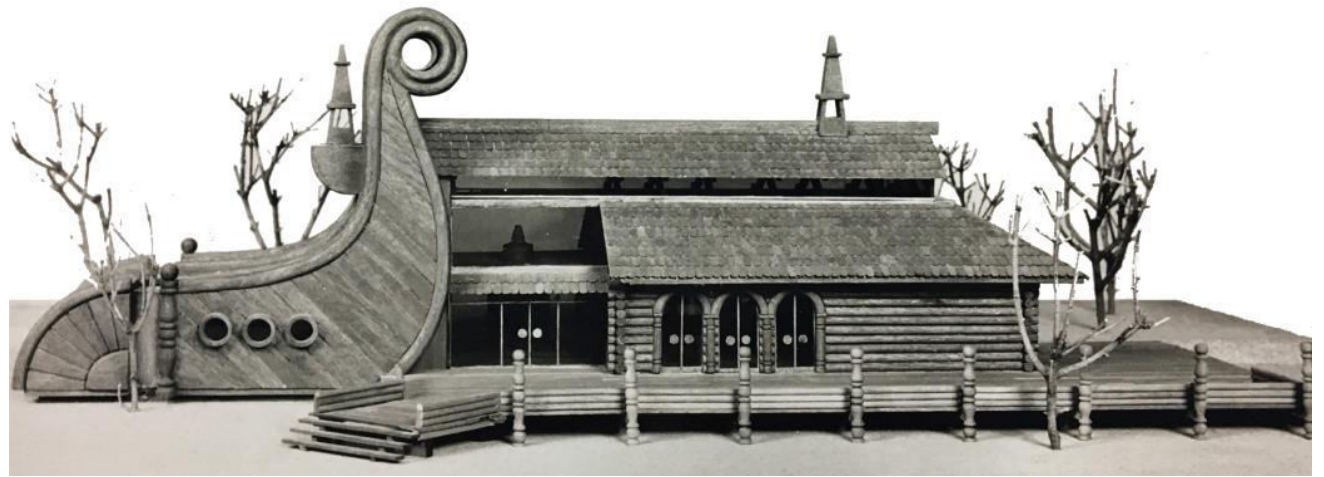

Source: documentation from the bureau "Romantic architecture".

The building consists of three floors, and the base is resolved in a rectangular raster. There is a central hall on the ground floor with a memorial plaque, a festive hall with 120 seats, a space for exhibiting activities and the souvenir shop as well as a café bar. The central zone of the first floor is intended for the permanent museum setting around which the library, the office and the loudspeaker station are organized. The ground floor has a small meeting room, warehouses and toilets.

The concept of the building rests on a symbolic and the form is treated sculpturally. Đokić presented the idea of the two nations' friendship with the symbolic permeation of the konak (traditional country house) and the Viking's ship. By the synthesis of two symbols, the original form was obtained on which the elements of the traditional Serbian log cabin and the prow of the ship are clearly visible. By directing these elements to the 
verticals or horizontals, the author wanted to emphasize the courage and defiance of the Norwegian people and friendshipness and humanism of Yugoslav people (Đokić, 1984, p. 37). The overall impression is enhanced by materialization in wood, which was used as a structural element, facade cover and as part of the interior. The building is composed of prefabricated elements of laminated wood which have been delivered from Norway for this purpose (Mlađenović, 1988).

For this object, Đokic won the prestigious Borba's award for the best architectural achievement in Serbia in 1987 (Mitrović, 1988). In the following year, he received the "Fourth of July" award for creativity and work of importance in cultivating the traditions of the People's Liberation War and the Socialist Revolution (Лукач, 1988).

This building was presenting a "living and active monument," which, apart from the reminiscing function and cultivation of tradition, encouraged the contacts and cultural cooperation of the two countries (Mitrović, 1988). It has been noted that during the first ten years of the objects existance, numerous activities were maintained in it: the annual March of Friendship, the annual assembly of the Yugoslav-Norwegian Society, the International Biennial of Art of Miniature, concerts and similar (tourist brochure, 1997). During the thirty years after its foundation, the building became a trademark of Gornji Milanovac and a rarity of architectural arts of Serbia (Миленковић, 2018).

Picture 5: JNA Club in Tivat, A. Đokić i B. Đunisijević, 1985-1989.

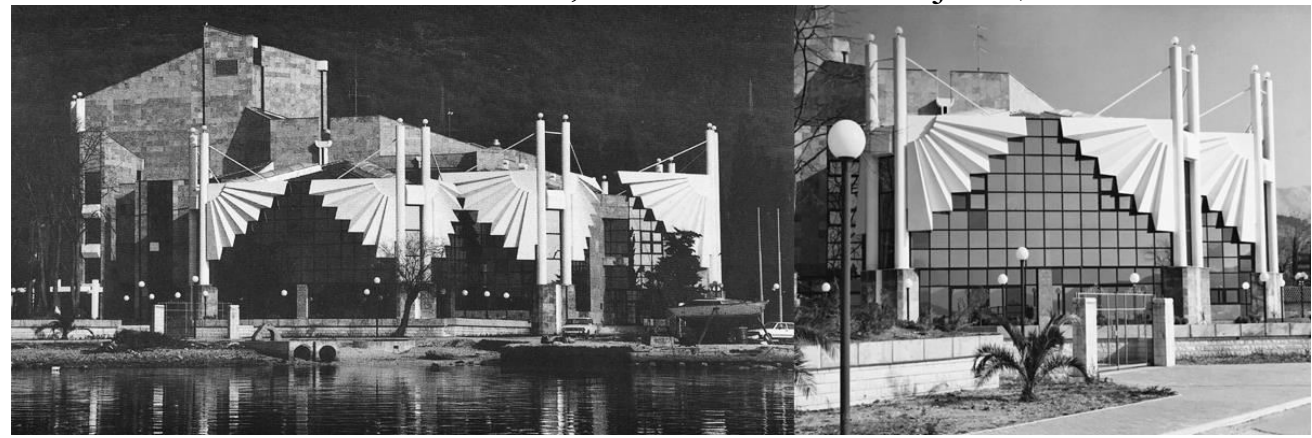

Sources: 3. Маневић, 1995, 135. (left); documentation from the bureau "Romantic architecture" (right).

The building of the Yugoslav National Army Club in Tivat (1985-1989) belongs to public facilities which complement the cultural and entertainment activities of tourists on site. The competition was announced for the building construction, where the first prize was won by the architects Aleksandar Đokić, Branislav Đunisijević and Dušan Tesić (interior) (Маневић, 1995, p. 194). 
The urban setting involved the area on the shores of the Bay of Boka Kotorska, all three sides surrounded by park's greenery. In the organization of the base, the central part of the building is occupied by a sitting hall, which continues into the space of the stage. Sideways to the main hall, smaller halls for different purposes are symmetrically positioned: library, exhibition space, billiard room, chess and shooting range. On both sides of the stage's space, administrative premises, sanitary knots and vertical communication for employees are located symmetrically. The staircase for the visitors is located in the corner sections of the entrance zone. The space is flexibly treated with a multi-purpose hall's system and circular communication flows. Adaptive restaurant's space was continuing in a spacious terrace located to the left of the main entrance. The height of the building increases from the entrance lot, through the seating hall, to the stage space, which is formed within the most massive volume. The shape of the object is jagged, and the volume's sizes are visually mitigated using the glazing surfaces (Поповић, 1990, p. 38). The construction of the building is made of reinforced concrete. For the materialization of the facade, next to the glass, the elements of gray polished marble were used. At the corners of the building, the height-dominant, doubled pillars and white dented elements were placed, amongst which are tensioned cables. These elements represent the main artistic accents on the facades, therefore their symbolism has caused different interpretations. Zoran Manevic recognized theirs association with the ships, while Darko Popovic interpreted them as the shellfish (Маневић, 1995, p. 132; Поповић, 1990, p. $38)$.

By this object, Djokic expressed his strong expressionist strivings, which, in addition to romantic imagination, represented an integral part of his mature stylistic expression. Although he used the symbolism of the artistic elements for linking to the site for which it was built, the overall visuelary expression of the building is strong and prominent. The building was awarded by the Diploma of the Fifth World's Architecture Biennial in Sofia in 1989 (Маневић, 1995).

It was noted that, during the mid-nineties of the twentieth century, in the JNA club the most important cultural and leisure activities in Tivat were maintained (Маневић, 1995, p. 132). During the first decade of the twentyfirst century Tivat began to gain international significance in the field of maritime traffic as a luxury marina Porto Montenegro. Businessman Peter Mank bought the building in 2006, nine years later the interior of the building was renovated and today, in the building, a club for sailing and sports within Porto Montenegro is situated (Vijesti, 2006; Luković, 2015). In 2016, Porto Montenegro has been bought by a state fund from Dubai (Beta, 2016; Telegraf, 2016). Since the construction of a luxury marina, Tivat became a tourist destination focused on high-yield tourists. Except interventions in the 
domain of the interior, the attractive exterior of the former Army Club is preserved in its original form and today it is mostly visited by elite tourists.

\section{CONCLUSION}

According to Aleksandar Djokić's words, the national orientation in arts and architecture represented "something sentimental and exalted" for him personally (Kadijević, 1996, p. 96). Due to ideological turmoil on the territory of Yugoslavia in the observed period, the term national was receiving different meanings. In this paper, four Đokić's projects were isolated, of which the complex on the Kadinjača and the house in Gornji Milanovac were formed by the ruling ideology, opposite to the hotel in Bečići and the Army Club in Tivat. In the context of the world market, projects formed under the influence of the ruling ideology fall under the domain of nationally-designed objects, although they actually represent its two poles. The complex at Kadinjača was formed during the most powerful ideology of Yugoslav particular, Third Way, which sought to unite all the republics within the federation. The aim was to create monumental forms, without emphasizing ethnic differences, which would represent the concept of "brotherhood and unity". The house of Yugoslav-Norwegian friendship was created during the strengthening period of nationalist currents within the Yugoslav state. In the architectural works of that period the return to the sources of folk architecture and more consistently involvement in the folk tradition were represented, which are evident in the applied forms and material selection on Đokić's object (Кадијевић, 2007, p. 341, 342).

The history on both of these objects testifies the strong influence of the ruling ideology on their attendance by visitors, but also points out the durability of their original architecture. Although, during some periods in recent history they were neglected and devastated, the stylistic expression of these objects was held to this day. The cultural significance of these facilities exceeds their utilitarian role in the tourism system.

The resort in Becici, originally designed in the spirit of current world trends, is now unrecognizable. The aesthetics of the building has been changed in the spirit of new architectural aspirations, and from the desire to achieve the effect of luxury, its primal authenticity has been devastated. Visual elements applied at the Army Club in Tivat reflect the universal symbolic meaning, which, with applied deconstruction and expressiveness, categorize this work as shaped in the international spirit. To this day, its architecture is unchanged, if we exclude interventions on the interior and its new purpose.

In Đokić's architectural opus, already in the mid-1990s, the buildings in Bečići, Gornji Milanovac and Tivat were distinguished as particularly 
prominent and as objects that "are leaving strong mark of Đokić's architectural aesthetic on its whole environment" (Kadijević, 1996, p. 97). We are inclined to consider architectural objects formed in the national spirit as a part of the cultural heritage. The famous artists's buildings created in the international spirit should also be recognized in the context of the heritage of one country, as the legacy of its prominent architects, which would prevent their devastation.

If we adopt the view that within the tourist activity "resources related to the system of inheritance are unlimited", resources should be developed independently of the limitating factors which national or supranational trends and ruling ideologies are representing (Ničić, 2015, p. 244). Clearly, this approach encounters numerous difficulties, but to a large extent contributes to the future prosperity of the tourist activity and the emancipation of the environment. The starting point for establishing a dialogue with other nations through tourism is overcoming the national trauma that inhibit dialogue with its own history. Properly treated architectural objects, as witnesses of certain periods of history, can contribute to the resolution of these traumas and, by their diversity, can also improve the country's tourist offer.

\section{REFERENCES}

1. Alfirević, Đ., 2016. Ekspresionizam u srpskoj arhitekturi. Beograd: Orion art.

2. Bakić, O., 2010. Marketing u turizmu. The ninth edition. Beograd: Univerzitet Singidunum.

3. Barcelona Tourist Guide. Gaudi Tours. [online] Available at: $<$ https://www.barcelona-tourist-guide.com/en/tour/gaudi-tours-inbarcelona-spain.html> [Accessed 25 November 2018].

4. Beta, 2016. Državni fond iz Dubaija preuzima danas Porto Montenegro. Beta 06.05.2016. Available at: $<$ http://beta.rs/ekonomija/ekonomija-region/31652-drzavni-fond-izdubaija-preuzima-danas-porto-montenegro> [Accessed 21 October 2017]

5. Cerbst, R., 2001. Gaudi: 1852-1926: Antonio Gaudi i Kornet - život posvećen arhitekturi. Beograd: IPS Media.

6. Čomić, Đ., 2015. Arhitektura kao faktor kvaliteta hotelskog proizvoda. SITCON. Beograd: Zbornik radova. Međunarodna naučna konferencija Univerziteta Singidunum. Konkurentnost turističke destinacije. 25 September 2015, p. 115-121.

7. Đokić, A., 1980. Spomenički kompleks Kadinjača. Izgradnja 1. p. 11-20.

8. Đokić, A., 1984. Kuća jugoslovensko-norveškog prijateljstva. Beograd: Izgradnja 4. p. 37-40. 
9. Ignjatović, A., 2010. Poricanje i obnova: arhitektura postmodernizma 1980-1991. in: Šuvaković, M. ed., 2010. Istorija umetnosti u Srbiji XX vek. Radikalne umetničke prakse. Beograd: Orion art. p. 663-670.

10. Ignjatović, A., 2012. Tranzicija i reforme: arhitektura u Srbiji 19521980. in: Šukvaković, M. ed., Istorija umetnosti u Srbiji XX vek. Realizmi i modernizmi oko Hladnog rata. Beograd: Orion art. p. 689710.

11. Кадијевић, А., 2007. Један век тражења националног стила у српској архитектури, средина XIX-средина XX века. The second edition. Београд: Грађевинска књига.

12. Kadijević, A., 1996. Osvrt na pređeni put, razgovor sa arhitektom Aleksandrom Đokićem. Prilozi proučavanju ličnosti i dela naših vodećih savremenih graditelja. in: Likovni život 59-60. Zemun februar/maj 1996. p. 93-98.

13. Kolins, Dž. R., 1997. Antonio Gaudi. in: Perović, M. R. ed., 1997. Istorija moderne arhitekture-antologija tekstova, Knjiga 1: Koreni modernizma. Beograd: Idea, Beograd 1997. p. 422-445.

14. Косин, П. и Пилчевић, Ђ., 1979. Били смо и остали доследни у остваривању идеала наше социјалистичке револуције. Велика свечаност на легендарној Кадињачи. Политика 24.09.1979. p. 1-3.

15. Кубуровић, М., 1985. Викиншки брод у Шумадији. Политика 07.06.1985. p. 8.

16. Kujundžić, V., 1980. Prihvatni centar - koncepcija i rešenje konstruktivnog sistema objekta. Izgradnja 4. p. 45-46.

17. Лукач, Р., 1988. Додељене награде и повеље „4. јул“ Савезног одбора СУБНОР-а Југославије. Револуција као инспирација, Београд: 4. јул 1360-1361. p. 24-25.

18. Маневић, 3., 1995. Александар Ђокић. Београд: Београдско машинско-графичко предузеће.

19. Manević, Z., 1982. Granice fantastike Aleksandra Đokića. IT novine. 11.01.1982. p. 17.

20. Маневић, 3., 1990. Романтична архитектура (catalog of the exhibition). Београд: Институт за историју уметности.

21. Manojlović-Pintar, O., 2014. Arheologija sećanja - spomenici $i$ identiteti u Srbiji 1918-1989, Beograd: Udruženje za društvenu istoriju: Čigoja.

22. Миленковић, А., 2018. Три деценије Куће српско-норвешког пријатељства. Политика 29.09.2018. p. 15.

23. Милетић-Абрамовић, Љ., 2007. Паралеле и контрасти, српска архитектура 1980-2005, Београд: Музеј примењене уметности.

24. Mitrović, M., 1988. Naša Stjern. Kuća jugoslovensko-norveškog prijateljstva u Gornjem Milanovcu - republička nagrada „Borbe“ za arhitekturu A. Đokić. Zagreb: OKO 05-19.05.1988. p. 23. 
25. Mlađenović, I., 1988. Kuća jugoslovensko-norveškog prijateljstva. Neizmjenjivi saputnik. Zagreb: OKO 14-28.01.1988. p. 15.

26. Ničić, M., 2015. Turizam zasnovan na baštini: ideološki procesi i implikacije. SITCON. Beograd: Zbornik radova. Međunarodna naučna konferencija Univerziteta Singidunum. Konkurentnost turističke destinacije. 25 September 2015. p. 242-247.

27. Пилчевић, Ђ., 1979. Уручене награде „Слободан ПенезићКрцун“. Политика 23.09.1979. p. 8.

28. Popesku, J., 2011. Menadžment turističke destinacije. Beograd: Univerzitet Singidunum.

29. Поповић, Д., 1990. Читање облика (Архитекте: А. Ђокић, Б. Ђунисијевић и Д. Тешић, Дом југословенске народне армије, Тиват). НИН 25.02.1990. p. 38.

30. Prague.eu The Official Tourist Website for Prague. Dancng House (Tančici dìm). [online] Available at: $<$ https://www.prague.eu/en/object/places/1643/dancing-house-tancicidum?back $=1>$ [Accessed 01 November 2018].

31. Prague Experience. Dancng House. [online] Available at: $<$ https://www.pragueexperience.com/places.asp?PlaceID=651> [Accessed 01 November 2018].

32. Путник, В., 2013. Естетика и улога меморијалних паркова у Југославији на примеру спомен комплекса „Кадињача“. in: Простори памћења 1, Зборник радова, Том 1, Архитектура (Кадијевић, А., Поповић, М. еds.), Београд: Филозофски факултет, Одељење за историју уметности. р. 290-301.

33. Путник, В., 2014. Меморијална скулптура Миодрага Живковића (Период 1960-1980). у: Јавни споменици и спомен обележја. Колективно памћење и/или заборав, Зборник радова (Живковић, H. ed.), Београд: Завод за заштиту споменика културе града Београда. p. 115-124.

34. Стефановић, С., 2010. Спомен-обележје Кадињача 1979-2009. Ужице: Ужсички зборник 34. p. 163-198.

35. Šastel, A., 1988. Pojam baštine. Split: Pogledi 3-4. vol. 18. p. 709723.

36. Štraus, I., 1991. Arhitektura Jugoslavije 1945-1990, Sarajevo: Svjetlost.

37. Telegraf, 2016. Porto Montenegro ima novog vlasnika: Arapi otkupili ceo nautičko-turistički kompleks u Tivtu. Telegraf 10.05.2016. Available at: <http://www.telegraf.rs/vesti/2136367-portomontenegro-ima-novog-vlasnika-arapi-otkupili-ceo-nautickoturisticki-kompleks-u-tivtu> [Accessed 21 October 2017]

38. Tourist brochure, 1997. Кућа југословенско-норвешког пријатељства. Споменик који живи. Горњи Милановац. 
39. Vijesti, 2006. Mank od danas vlasnik Arsenala i Doma vojske u Tivtu. Vijesti 28.10.2006. Available at: $<$ http://www.pcnen.com/portal/2006/10/28/mank-od-danas-vlasnikarsenala-i-doma-vojske-u-tivtu/> [Accessed 21 October 2017]

40. Luković, S., 2015. Novi Porto Montenegro jahting klub za nautičku klijentelu. Vijesti 17.07.2015. Available at: <http://www.vijesti.me/vijesti/novi-porto-montenegro-jahting-klubza-nauticku-klijentelu-842966> [Accessed 21 October 2017]

41. Whitfield, M., 2018. Gaudi: A Cultural Icon for Tourism. The International Angle, [e-journal] 14. January 2018. Available at: $<$ http://theinternationalangle.com/index.php/2018/01/14/gaudi-acultural-icon-for-tourism/> [Accessed 25 November 2018].

Received: 3 December, 2018

Accepted: 23 December, 2018 